\title{
Pseudomonas pyocyanea and the arginine dihydrolase system
}

\author{
J. J. TAYLOR AND J. L. WHITBY \\ From the Department of Clinical Pathology, Queen Elizabeth Hospital, Birmingham
}

SYNOPSIS Non-pigmented strains of Pseudomonas pyocyanea occur frequently and this organismp has only limited activity in conventional biochemical tests; 50 strains were tested for the्v presence of arginine dihydrolase and found positive whereas only Salmonella sp. and Enterobacter sp among other Gram-negative species were positive. The test for arginine dihydrolase is rapid and simple and suitable for routine use.

Ps. pyocyanea is a common infecting organism usually recognized in the routine laboratory by colonial morphology, pigment production, and positive oxidase and catalase tests, but for some time it has been recognized that strains may not be pigmented on first isolation (Gaby and Free, 1953). For such organisms growth on cetrimide agar (Lowbury and Collins, 1955) and ultra-violet fluorescence (Lowbury, 1951) are helpful but not absolutely specific. In our hands the cytochrome oxidase test (Ewing and Johnson, 1960) may also be difficult to interpret in poorly pigmented strains. Flagella straining, decarboxylase tests, and the use of special fermentation conditions (Hugh and Leifson, 1953) are not usually performed in a routine hospital laboratory. Conventional carbohydrate tests are not very helpful although acid is usually produced in glucose after a variable period of time.

Alcaligenes faecalis is a non-pigmented organism but it gives positive oxidase, cytochrome oxidase, and catalase tests. This species has no action on glucose and is without action on other routine carbohydrates. A further test which rapidly distinguishes Alcaligenes from Pseudomonas is desirable as a series of negative tests is hardly determinative. Another organism which has been confused with Pseudomonas is Achromobacter anitratus but this should not really give rise to difficulties as typical strains of $A$. anitratus are oxidase and cytochrome oxidase-negative and produce acid in glucose, xylose, and arabinose.

Thornley (1960) described a test for the presence of arginine dihydrolase which distinguished between Pseudomonas sp. (positive) and Achromobacter sp.

Received for publication 15 August 1963. (negative). This test seemed worth investigating as ap additional measure for the identification of $P s \vec{c}$ pyocyanea, and the behaviour of a variety of otheg Gram-negative species has been tested to determine how far this enzyme is specific to Pseudomona@ among Gram-negative bacterial species of medica importance.

\section{MATERIALS AND METHODS}

BACTERIAL CULTURes Strains of Ps. pyocyanea were consecutive isolates from routine material at the Queen Elizabeth Hospital. Four strains of $A$. anitratus (nos. 7363, 7364, 7462, and 1802) and four strains of Alcalī genes faecalis (nos. 415, 655, 8764, and 8769) were obtained from the National Collection of Type Cultures One strain each of Aeromonas liquefaciens, Pasteurelt septica, Salmonella bredeny, and Shigella flexneri were obtained from the Children's Hospital, Birmingham? Brucella abortus and six Salmonella sp. were obtaine $\$$ from the Bacteriology Department of the Birmingham Medical School. Other organisms were isolated from routine laboratory material from the Queen Elizabet Hospital. In addition 43 examples of Salmonella sper were tested in the system by Dr. S. P. Lapage of the Salmonella Reference Laboratory, Colindale.

TEST METHODS Oxidase activity was tested on filter paper impregnated with tetramethyl-p-phenylenediamine (Kovacs, 1956).

Cytochrome oxidase activity was detected by the addition of $1 \%$ alcoholic alpha-naphthol and $1 \%$ aqueous para amino-dimethylaniline oxalate to 18-hou cultures on nutrient agar slopes (Ewing and Johnsong 1960).

Other routine tests were performed by the methoos described in the Report of the Subcommittee on Entere bacteriaceae (1958). 
Arginine dihydrolase activity was determined by the method of Thornley (1960). The medium is as follows:Peptone....................... $0 \cdot 1 \%$

Sodium chloride .................. $0.5 \%$

Dipotassium hydrogen phosphate. . . . . . . . 0.03\%

N.Z. agar ..................... $0.3 \%$

Phenol red $\ldots \ldots \ldots \ldots \ldots \ldots \ldots \ldots \ldots \ldots . \ldots \ldots \ldots$

L-arginine monohydrochloride . . . . . . . $1.0 \%$

pH $7 \cdot 2$

This medium is sterilized by autoclaving at $15 \mathrm{lb}$. for 20 minutes, distributed in $2 \mathrm{ml}$. amounts in $5 \mathrm{ml}$. bijou bottles, and stored at $4^{\circ} \mathrm{C}$.

The medium is inoculated by stab and the surface then covered with a $5 \mathrm{~mm}$. layer of sterile liquid paraffin and the screw cap firmly affixed. After overnight incubation the whole of the medium assumes a pink colour in a positive test. Negative tests remain unchanged or turn yellow (acid production).

Inhibition studies were carried out with the same medium and $10^{-3} \mathrm{M}$ cyanide and $10^{-3} \mathrm{M}$ arsenite were added after sterilization.

In addition to the arginine dihydrolase test (Thornley, 1960), the arginine test (Møller, 1955), the medium for which differs by the addition of glucose, pyridoxal, and beef extract, was performed both with and without the addition of inhibitors.

\section{RESULTS}

In a preliminary study 26 consecutive strains of $P s$. pyocyanea, identified as already indicated by their behaviour in conventional laboratory tests, were tested under identical conditions to those described by Thornley. These differ from those of the method ultimately employed in that a second bottle is inoculated to which no liquid paraffin is added. Table I shows that the 'closed' or paraffincontaining bottle was uniformly positive but the 'open' bottle yielded variable results. As a consequence only the 'closed' bottle was used for subsequent tests.

\section{TABLE I}

INITIAL STUDY

\begin{tabular}{ccccccc}
$\begin{array}{l}\text { Number of Strains of } \\
\text { Ps. pyocyanea Tested }\end{array}$ & \multicolumn{2}{c}{ 'Open' Bottle } & & \multicolumn{2}{c}{ 'Closed' Bottle } \\
\cline { 2 - 3 } & Positive & Negative & & Positive & Negative \\
\hline 26 & 15 & 11 & & 26 & 0
\end{tabular}

Table II shows the results obtained using the 'closed' bottle arginine test with a number of bacterial species. The tests were only incubated for 48 hours and the results were first read after overnight incubation although positive tests with Pseudomonas strains can frequently be observed within eight to 12 hours. It can be seen that among the Gram-negative organisms tested only $P s$. pyocyanea gave uniform rapid positive results. As some Salmonella and a few Enterobacter cloacae
TABLE II

BEHAVIOUR OF VARIOUS BACTERIAL SPECIES OF MEDICAL IMPORTANCE IN THE ARGININE DIHYDROLASE TEST READ AFTER 48 HOURS

Organism No. Tested Positive Negative

Brucella abortus

Neisseria pharyngis

Pasteurella septica

Pasteurella pseudotuberculosis

Haemophilus infuenzae

Salmonella subgenus 1

Salmonella subgenus 2

Arizona

Shigella sp.

Escherichia coli

Proteus sp.

Providence sp.

Enterobacter sp.

Serratia sp.

Hafnia sp.

Klebsiella sp.

Citrobacter sp.

Achromobacter sp.

Achromobacter anitratus

Flavobacterium sp.

Aeromonas liquefaciens

Alcaligenes sp.

Pseudomonas pyocyanea

Staphylococcus pyogenes

Streptococcus faecalis

Bacillus sp.

Candida albicans

Nocardia asteroides

Actinomyces bovis

No. Tested Positive Negative

${ }^{1}$ For further data on these strains see Table 111.

${ }^{2}$ Positive at room temperature, not at $37^{\circ} \mathrm{C}$.

strains were found to be positive within two days, incubation was continued for a further four days to see whether the majority of these strains would eventually break down arginine in the test system. Table III shows the findings and the time taken for the reaction to occur. The majority of strains of both these species were ultimately found to be positive or weakly positive. However, the activity of PS. pyocyanea was much more rapid. Nevertheless this finding and the fact that certain Gram-positive species are also positive makes the method un-

\section{TABLE III}

BEHAVIOUR OF SALMONELLA AND ENTEROBACTER CLOACAE STRAINS IN THE ARGININE DIHYDROLASE TEST

\begin{tabular}{|c|c|c|c|c|c|c|c|c|}
\hline \multirow{2}{*}{$\begin{array}{l}\text { No. of } \\
\text { Strains } \\
\text { Tested }\end{array}$} & \multirow[t]{2}{*}{ Species } & \multirow[t]{2}{*}{ Result } & \multicolumn{6}{|c|}{ Time of Incubation (days) } \\
\hline & & & $I$ & 2 & 3 & 4 & 5 & 6 \\
\hline 43 & $\begin{array}{l}\text { Salmonella } \\
\text { (subgenus I) }\end{array}$ & $\begin{array}{l}\text { Negative } \\
\text { Weak positive } \\
\text { Positive }\end{array}$ & $\begin{array}{r}25 \\
6 \\
12\end{array}$ & $\begin{array}{r}21 \\
3 \\
19\end{array}$ & $\begin{array}{r}16 \\
6 \\
21\end{array}$ & $\begin{array}{r}16 \\
6 \\
21\end{array}$ & $\begin{array}{r}13 \\
8 \\
22\end{array}$ & $\begin{array}{r}13 \\
8 \\
22\end{array}$ \\
\hline 6 & $\begin{array}{l}\text { Salmonella } \\
\text { (subgenus II) }\end{array}$ & $\begin{array}{l}\text { Negative } \\
\text { Weak positive } \\
\text { Positive }\end{array}$ & $\begin{array}{l}2 \\
1 \\
3\end{array}$ & $\begin{array}{l}1 \\
0 \\
5\end{array}$ & $\begin{array}{l}0 \\
1 \\
5\end{array}$ & $\begin{array}{l}0 \\
1 \\
5\end{array}$ & $\begin{array}{l}0 \\
0 \\
6\end{array}$ & $\begin{array}{l}0 \\
0 \\
6\end{array}$ \\
\hline 16 & $\begin{array}{l}\text { Enterobacter } \\
\text { cloacae }\end{array}$ & $\begin{array}{l}\text { Negative } \\
\text { Weak positive } \\
\text { Positive }\end{array}$ & $\begin{array}{r}14 \\
2 \\
0\end{array}$ & $\begin{array}{r}13 \\
1 \\
2\end{array}$ & $\begin{array}{r}11 \\
3 \\
2\end{array}$ & $\begin{array}{l}8 \\
3 \\
6\end{array}$ & $\begin{array}{l}5 \\
6 \\
5\end{array}$ & $\begin{array}{l}5 \\
4 \\
7\end{array}$ \\
\hline
\end{tabular}


suitable for use as a screen test for Pseudomonas sp. in the presence of a mixed bacterial flora, e.g., a wound swab.

\section{DISCUSSION}

Ackermann (1910) investigated bacterial putrefaction and demonstrated the production of putrescine, which he showed to be derived from arginine. This process has been confirmed more recently in Enterobacteriaceae (Møller, 1955), and the biochemical sequence is shown in Figure 1. Arginase is a monohydrolase and requires pyridoxal as a cofactor.

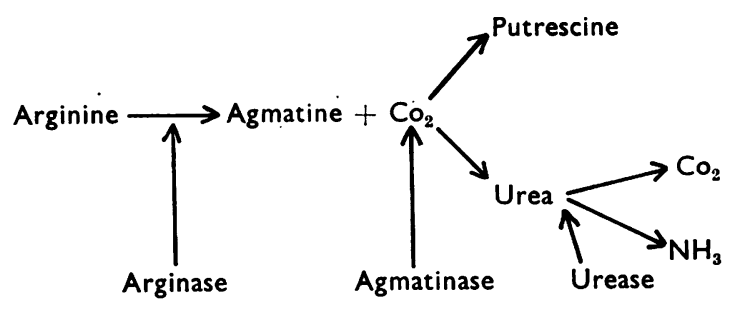

FIG. 1. Arginine-urea pathway

Earlier observation (Ackermann, 1908) showed that ornithine was also producèd from arginine during putrefaction. Hino (1924) showed Ps. pyocýanea to be capable of attacking the guanide group of arginine, and Horn (1933) first demonstrated the arginine desimidase (arginine $\rightarrow$ ornithine) system using this organism. A similar mechanism was investigated in Streptococcus sp. (Gale, 1940) and Str. faecalis (Sekine, 1947). Working with the latter, Oginsky and Gehrig (1952) established citrulline as an intermediary, and showed that at least two enzyme systems were involved and that the production of ornithine by this mechanism was independent of phosphate-bound energy (Fig. 2).

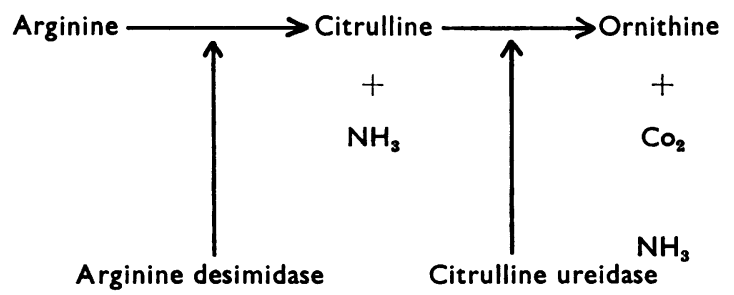

FIG. 2. Anaerobic breakdown of arginine (argininedihydrolase system).

Failure to detect citrulline earlier appears to have been attributable to impermeability of the cell wall, since, with cell-free extracts obtained by ultrasonic disintegration, or with acetone-dried extracts, Knivett (1952) demonstrated its presence by chroma- tography. He further showed that citrulline was attacked only slowly by intact cells and not at all by cetavlon-treated cells (in the absence of A.T.P.).

Slade, Doughty, and Slamp (1954) demonstrate the presence of this mechanism in a 'Pseudomonad' $\overline{\bar{n}}$. and similar reports have been made by other workers (Akamatsu and Sekine, 1951; Slade and Slamp, 1952; Schmidt, Logan, and Tytell, 1952). Theis arginine dihydrolase system has been demonstrated 5 in Streptococcus, where citrulline production hasbeen used as a classification measure, and is knownw to occur in other Gram-positive bacteria, e.g. Lactobacillus, Staphylococcus, and Clostridiump (Hills, 1940) and Corynebacterium (Cowan and Steel, 1961). It also occurs in baker's yeast (Roche' and Lacombe, 1952) and Chlorella pyrenoidosañ (Horn, 1933). Arginine dihydrolase activity in $n_{0}^{N}$ Gram-negative organisms is less well documented although several 'arginine' tests have been intro- $\vec{z}$ duced. Møller (1955) tested with Nessler's solutiono after four days' incubation. A positive result was? taken to indicate the presence of arginine dihydrolase in the system; however, it is necessary to exclude theo presence of urease before making this assumption: Sherris, Shoesmith, Parker, and Breckon (1959)0 compared Møller's test with a qualitative ands quantitative test of their own design. These authorso noted the rapid breakdown of arginine by Pseudo 0 monas sp. Hormaeche and Munilla (1957) omitted pyridoxal from Møller's medium and found that $146 \overrightarrow{0}$ out of 169 strains of Enterobacter cloacae were positive. Dickinson and Mocquot (1961) also used this modification and found 29 strains of 'cloaca? which gave positive results. Thornley (1960) omittect both glucose and pyridoxal, thus presenting more exacting conditions and anaerobiosis. She found $\mathrm{B}$. good differentiation between Pseudomonas (positive) and Achromobacter (negative).

Experimental data indicate a positive result in Thornley's test to be attributable to arginine? dihydrolase activity; thus Str. faecalis, which has noo decarboxylase activity, gives a positive result (see Table II). All amino-acid decarboxylases ares inhibited by cyanide (Gale, 1940). The addition of cyanide to the test was without effect in Thornley's medium. Arsenite at $10^{-3} \mathrm{M}$ causes $50 \%$ inhibition of arginine desimidase (Oginsky, 1955). When incubated with arsenite, 41 out of 50 normally positivet strains of Ps. pyocyanea gave a negative result.\$\$ Utilizing Møller's test, both cyanide and arsenite produced marked inhibition (Table IV) suggestingo that other pathways are also involved in the latterल test.

At least two pathways of arginine breakdown are known, and in the literature the terms 'arginase and 'arginine dihydrolase' have been used indis? 
TABLE IV

EFFECT OF CYANIDE OR ARSENITE ON BEHAVIOUR OF 50 STRAINS OF PS. PYOCYANEA IN ARGININE TESTS

\begin{tabular}{lcc} 
Test & Positive & Negative \\
\hline Thornley's test & 50 & 0 \\
Thornley's test $+10^{-3} \mathrm{M}$ cyanide & 50 & 0 \\
Thornley's test $+10^{-3} \mathrm{M}$ arsenite & 9 & 41 \\
Møller's test & 50 & 0 \\
Møller's test $+10^{-3} \mathrm{M}$ cyanide & 12 & 38 \\
Møller's test $+10^{-3} \mathrm{M}$ arsenite & 11 & 39
\end{tabular}

criminately on occasion. Over 20 years ago it was proposed that this laxity of terminology be abandoned (Hills, 1940) but confusion still exists. Our results show that whereas other pathways may also be involved in Møller's test, anaerobic breakdown of arginine in Thornley's medium appears to depend specifically on arginine dihydrolase activity. This probably accounts for the more limited range and greater specificity of the present test, which, with the Gram-negative organisms tested, gave positive results only with Pseudomonas, Salmonella, and some Enterobacter.

The value of the present test lies in providing a reliable positive test to aid in distinguishing between Gram-negative organisms which are inactive in conventional biochemical tests. Ps. pyocyanea, an important hospital pathogen, is thus easily and rapidly distinguished from Alcaligenes and Achromobacter. Salmonella and Enterobacter are readily distinguished by their greater fermentative activity and a negative oxidase reaction. The test is recommended for routine laboratory use as the medium is simple to prepare and results are available after overnight incubation.

Our thanks are due to Dr. S. P. Lapage of the Salmonella Reference Laboratory, Colindale, for testing a large number of Salmonella species in the system for us.

\section{REFERENCES}

Ackermann, D. (1908). Hoppe-Seylers Z. physiol. Chem., 56, 305. (1910). Ibid., 65, 504; 69, 273.

Akamatsu, S., and Sekine, T. (1951). J. Biochem. (Tokyo), 38, 349. Cowan, S. T., and Steel, K. J. (1961). J. Hyg. (Lond.), 59, 357.

Dickinson, A. B., and Mocquot, G. (1961). J. appl. Bact., 24, 252.

Ewing, W. H., and Johnson, J. G. (1960). Int. Bull. bact. Nomencl., 10, 223.

Gaby, W. L., and Free, E. (1953). J. Bact., 65, 746.

Gale, E. F. (1940). Biochem. J., 34, 392 and 853.

Hills, G. M. (1940). Ibid., 34, 1057.

Hino, S. (1924). Hoppe-Seylers Z. physiol. Chem., 133, 100.

Hormaeche, E., and Munilla, M. (1957). Int. Bull. bact. Nomencl., 7, 1. Horn, F. (1933). Z. phys. Chem., 216, 244.

Hugh, R., and Leifson, E. (1953). J. Bact., 66, 24.

Lowbury, E. J. (1951). J. clin. Path., 4, 66.

- and Collins, A. G. (1955). Ibid., 8, 47.

Knivett, V. A. (1952). Biochem. J., 50, 30 p.

Kovacs, N. (1956). Nature (Lond.), 178, 703.

Møller, V. (1955). Acta path. microbiol. scand., 36, 158

Oginsky, E. L. (1955). In Methods of Enzymology, edited by S. P. Colowick, and N. O. Kaplan, vol 2, p. 374. Academic Press, New York.

-, and Gehrig, R. F. (1952). J. biol. Chem., 198, 791 and 799.

Report (1958). Int. Bull. bact. Nomencl., 8, 25.

Roche, J., and Lacombe, G. (1952). Biochim. biophys. Acta (Amst.), 9, 687.

Schmidt, S. C., Logan, M. A., and Tytell, A. A. (1952). Fed. Proc., 11, 283.

Sekine, T. (1947). J. Biochem. (Tokyo), 19, 79.

Sherris, J. C., Shoesmith, J. G., Parker, M. T., and Breckon, D. (1959). J. gen. Microbiol., 21, 389.

Slade, H. D., Doughty, C. C., and Slamp, W. C. (1954). Arch. Biochem., 48, 338.

- and Slamp, W. C. (1952). J. Bact., 64, 455.

Thornley, M. J. (1960). J. appl. Bact., 23, 37. 